\title{
The response of calcareous nannofossil assemblages to the Paleocene Eocene Thermal Maximum at the Walvis Ridge in the South Atlantic
}

\author{
Isabella Raffi ${ }^{\mathrm{a}, *}$, Jan Backman ${ }^{\mathrm{b}}$, James C. Zachos ${ }^{\mathrm{c}}$, Appy Sluijs ${ }^{\mathrm{d}}$

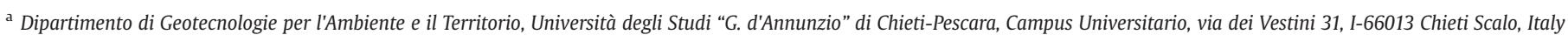 \\ ${ }^{\mathrm{b}}$ Department of Geology and Geochemistry, Stockholm University, SE-10691 Stockholm, Sweden \\ c Department of Earth and Planetary Sciences, UCSC, Santa Cruz, CA 95064, USA \\ d Palaeoecology, Institute of Environmental Biology, Utrecht University. Laboratory of Palaeobotany and Palynology, Budapestlaan 4, 3584 CD, Utrecht, The Netherlands
}

\section{A R T I C L E I N F O}

\section{Article history:}

Received 4 July 2008

Received in revised form 10 December 2008

Accepted 11 December 2008

\section{Keywords:}

Calcareous nannofossils

PETM

Uniquely rapid evolution

Paleoecology

Photic zone environment

\begin{abstract}
A B S T R A C T
Compositions and abundances of calcareous nannofossil taxa have been determined in a ca 170 kyrs long time interval across the Paleocene/Eocene boundary at $1-\mathrm{cm}$ to $10-\mathrm{cm}$ resolution from two ODP Sites (1262, 1263) drilled along the flank of the Walvis Ridge in the South Atlantic. The results are compared to published data from ODP Site 690 in the Weddell Sea. The assemblages underwent rapid evolution over a 74 kyrs period, indicating stressed, unstable and/or extreme photic zone environments during the PETM hyperthermal. This rapid evolution, which created 5 distinct stratigraphic horizons, is consistent with the restricted brief occurrences of malformed and/or weakly calcified morphotypes. The production of these aberrant morphotypes is possibly caused by major global scale changes in carbon cycling in the oceanatmosphere system, affecting also photic zone environments. No marked paleoecologically induced changes are observed in abundances of the genera Discoaster, Fasciculithus and Sphenolithus at the Walvis Ridge sites. Surprisingly, there is no significant correlation in abundance between these three genera, presumed to have had a similar paleoecological preference for warm and oligotrophic conditions.
\end{abstract}

(c) 2008 Elsevier B.V. All rights reserved.

\section{Introduction}

The Paleocene Eocene Thermal Maximum (PETM) is a brief climate perturbation that is characterized by a global increase in temperature and a massive injection of ${ }^{13} \mathrm{C}$-depleted carbon into the oceanatmosphere system (Kennett and Stott, 1991; Dickens et al., 1995; Zachos et al., 2001, 2005; Sluijs et al., 2006). This injection imprinted a negative carbon isotope excursion (CIE) in sedimentary components that, including onset and recovery, lasted approximately 170 kyrs (Röhl et al., 2007; Sluijs et al., 2007; Abdul Aziz et al., 2008), and which is now used to approximate the Paleocene-Eocene boundary (Aubry et al., 2007).

Marine biotic response to the climatic and carbon cycle changes was significant (Sluijs et al., 2007). This includes calcareous nannofossil assemblages which underwent significant change on a global scale. The diversity of the Paleocene genus Fasciculithus decreased substantially (Raffi et al., 2005), with only Fasciculithus tympaniformis and Fasciculithus involutus prevailing into the lowermost Eocene. Within the CIE, the genus Rhomboaster evolved rapidly together with members of the genus Tribrachiatus (Romein, 1979), as well as the malformed and short ranged Discoaster araneus and/or Discoaster anartios (Bybell and Self-Trail, 1995; Cramer et al., 2000; Monechi et al.,

\footnotetext{
* Corresponding author. Fax: +39 08713556047.

E-mail address: raffi@unich.it (I. Raffi).
}

2000; Kahn and Aubry, 2004; Tremolada and Bralower, 2004; Agnini et al., 2007a). The Rhomboaster-D. araneus/anartios association is restricted to the PETM (Aubry, 2001; Kahn and Aubry, 2004; Aubry et al., 2007). This assemblage has been observed in many sections and appears to represent a ubiquitous evolutionary event (Raffi et al., 2005). The abundances of Fasciculithus continue to decrease through the PETM, culminating in its extinction shortly after the PETM. In contrast, the abundance of the genus Zygrhablithus (mainly $Z$. bijugatus) increases within the PETM. This pattern has been recorded in several deep-sea and land-based sections (Tremolada and Bralower, 2004), but is not a global event. In fact, while the decline and successive demise of Fasciculithus is global, the increase of Zygrhablithus has been recorded in some tropical, mid- and high latitude regions but it is absent in other equatorial and mid-latitude regions (Raffi et al., 2005). All the above nannofossil events are restricted to the PETM interval, and are thought to be related to the unusual transient paleoenvironmental conditions that occurred in the photic zone that characterizes the PETM/CIE (Bralower, 2002; Agnini et al., 2007a).

Only a few open ocean sites with complete Paleocene/Eocene transitions and relatively well-preserved nannofossil assemblages have been studied in detail. These include the high latitude Southern Ocean Drilling Program (ODP) Site 690 in the Weddell Sea (Bralower, 2002), the tropical Pacific Ocean ODP Site 1209 (Gibbs et al., 2006), the tropical Atlantic Ocean ODP Site 1260 (Mutterlose et al., 2007), and the hemipelagic Tethyan Ocean Forada section (Agnini et al., 2007a). 
Assemblage shifts during the PETM have been interpreted as representing changes in paleoproductivity, from increased eutrophy in neritic-marginal seas to increased oligotrophy in the open ocean (Bralower, 2002; Tremolada and Bralower, 2004; Gibbs et al., 2006; Giusberti et al., 2007). For example, increasing relative abundances of Discoaster and Fasciculithus at Site 690, and increasing abundances of Discoaster, Fasciculithus and Sphenolithus at Site 1209, have been interpreted to represent more oligotrophic, but also warmer environments (Bralower, 2002; Gibbs et al., 2006). The PETM is also characterized by abundance shifts of nannofossil taxa that are considered to thrive during colder-water conditions and/or which were adapted to mesotrophic-eutrophic environments (Bralower, 2002; Tremolada et al., 2007), such as Toweius and Chiasmolithus. In the Tethyan Forada section, changes involve an increase of the supposedly eutrophic Coccolithus and Ericsonia and a concomitant decrease of the supposedly oligotrophic Octolithus sp.1 and Sphenolithus. Agnini et al. (2007a) interpreted this as a response to nutrient enhanced conditions induced by increase in weathering and runoff during the PETM. All the above variations are considered to indicate an unstable photic zone environment. At ODP Site 1260 in the tropical western Atlantic Ocean, the observed nannofossil abundance patterns show no distinct patterns (Mutterlose et al., 2007). For example, the abundances of various stenotopic taxa such as the "oligotrophic" Discoaster spp., Sphenolithus and Discoaster, and the "eutrophic" Chiasmolithus and Campylosphaera are either invariant across the PETM, or show no covariance.

In addition to changes in photic zone temperatures and nutrient cycling, the plankton assemblages may have been influenced by ocean acidification due to the massive input of carbon dioxide to the water column during the $\mathrm{CIE}$. If the rate of carbon injection was rapid enough to substantially decrease carbonate ion concentrations and $\mathrm{pH}$ of the surface ocean, it should have influenced calcareous nannoplankton. Experiments with modern flora have demonstrated both adverse and positive effects on nannoplankton in response to higher $\mathrm{pCO}_{2}$ and reduced pH (Riebesell et al., 2000; Zondervan et al., 2001; Rost and Riebesell, 2004; Langer et al., 2006; Iglesias-Rodriguez et al., 2008).

Here, we have studied two pelagic sections spanning the Paleocene/Eocene boundary recovered during ODP Leg 208 in the subtropical South Atlantic (Fig. 1) (Zachos et al., 2004), in order to determine compositional and abundance changes in calcareous nannofossil assemblages that are independent of preservation artifacts. These data will be employed to investigate the response of calcareous nannoplankton to photic zone changes in temperature, nutrient concentration and carbon geochemistry across the Paleocene/Eocene boundary interval and the PETM. The two sites, 1263 and 1262, represent the shallow and deep end members of a depth transect of sites drilled on the flank of the Walvis Ridge, at 1500 and $3500 \mathrm{~m}$ paleodepth, respectively (Zachos et al., 2004). The onset of the PETM at both the shallow Site 1263 and the deep Site 1262 is marked by clay layers, resulting from CCD rise (Zachos et al., 2005). Correlation of the sites based on $\partial^{13} \mathrm{C}$ records has revealed that the carbonate content across the recovery interval increases first at shallower and later at deeper depths, evidencing a gradual deepening of the CCD and lysocline. Because the sites are located so close $(150 \mathrm{~km})$ to each other, differences in nannofossil assemblages at any given time likely depend on preservational differences rather than differences in composition and relative abundances among the plankton communities. The nannoplankton input signal is hence assumed to have been identical at the two sites.

\section{Material and methods}

Samples were collected from the critical PETM interval at Sites 1262 (4755 m water depth; $1.3 \mathrm{~m}$ investigated) and 1263 (2717 m water depth; 3 m investigated). Core photos, carbonate concentration curves and bulk sediment carbon isotope records from these two intervals are shown by Zachos et al. (2005). Quantitative analyses on calcareous nannofossil assemblages were carried out on U-channel sample sets. Specifically, 200 samples were analyzed from a $3 \mathrm{~m}$ interval at Site 1263, between 333 and 336 mcd (from 1263C-14H-1, $31 \mathrm{~cm}$ to $1263 \mathrm{D}-4 \mathrm{H}-1,100 \mathrm{~cm}$ ). This $3 \mathrm{~m}$ interval corresponds to about 170 kyrs (Röhl et al., 2007). At Site 1262, 79 samples were analyzed from a $1.3 \mathrm{~m}$ interval between 139 and $140.31 \mathrm{mcd}$ (from 1262B-15H2, $79 \mathrm{~cm}$ to $1262 \mathrm{~B}-15 \mathrm{H}-3,89 \mathrm{~cm}$ ). Age estimates of the investigated nannofossil biostratigraphic events are not provided here, although the relative distance, in terms of timing, between each successive event is provided following Röhl et al. (2007) and Westerhold et al. (2007). The samples were processed using standard techniques to prepare smear-slides, and subsequently analyzed with a polarizing microscope at $1250 \times$ magnification.

The taxa considered in the present paper are listed in Appendix A, and most are referenced in Perch-Nielsen (1985) and Aubry (1984,

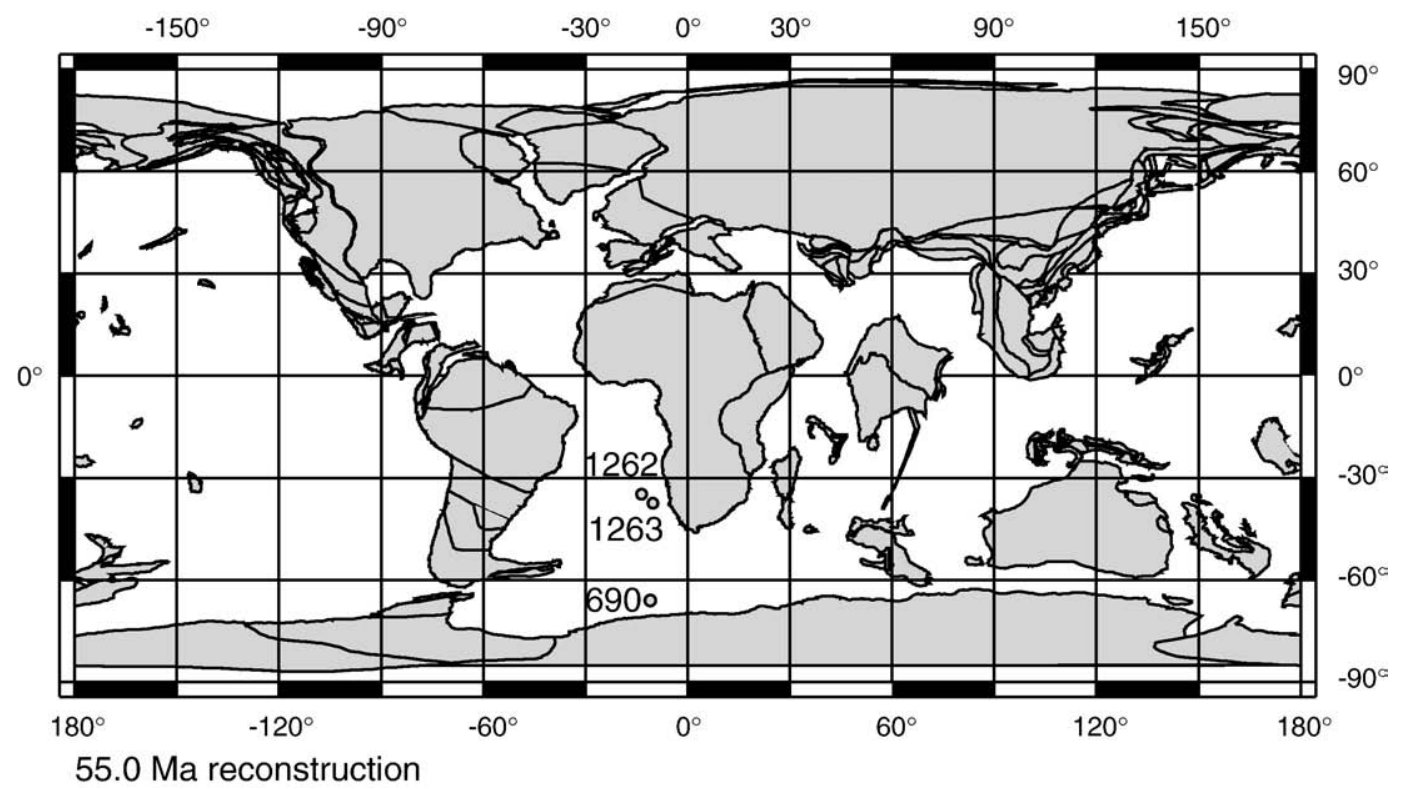

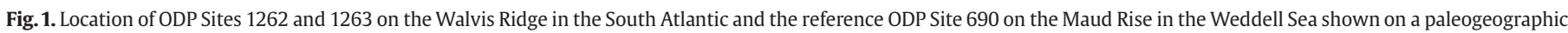
map at $55 \mathrm{Ma}$ (http://www.odsn.de/odsn/services/paleomap/paleomap.html). 
1988, 1989, 1990). The taxonomy of most taxa are generally well established, except for the much debated genera Rhomboaster and Tribrachiatus (Perch-Nielsen, 1985; Bybell and Self-Trail, 1997; Aubry et al., 2000; Wei and Zhong, 1996; von Salis et al., 2000; Raffi et al., 2005). Although some investigators have grouped the two under the genus Rhomboaster and recombined all species within Tribrachiatus into Rhomboaster, we prefer to distinguish both genera, only recognizing the following Rhomboaster taxa: Rhomboaster cuspis and the Rhomboaster calcitrapa group, which includes the species Rhomboaster intermedia, Rhomboaster bitrifida and Tribrachiatus spineus.

Nannofossil abundance data in the U-channel samples were generated by counting specimens in a prefixed area of the slide, in which each field-of-view has a relatively constant nannofossil density, and expressed as number of specimens $/ \mathrm{mm}^{2}$ (Backman and Shackleton, 1983; Backman and Raffi, 1997). The taxa selected for counting are considered to be sensitive to changes in temperature and nutrient concentrations according to Bralower (2002). In order to be able to directly compare our results with data from Site 690 we generated relative abundance data on 73 samples across the PETM, and performed two series of counts, following the methodology of Bralower (2002). A total of 300 specimens from the whole assemblage was initially counted, including smaller $(\sim 3 \mu \mathrm{m})$ specimens and all specimens larger than one half the original nannofossil. Specimens belonging to the genera Coccolithus, including rare Ericsonia, and Toweius, represent $40-80 \%$ of the total assemblage in most samples.

Site 1263
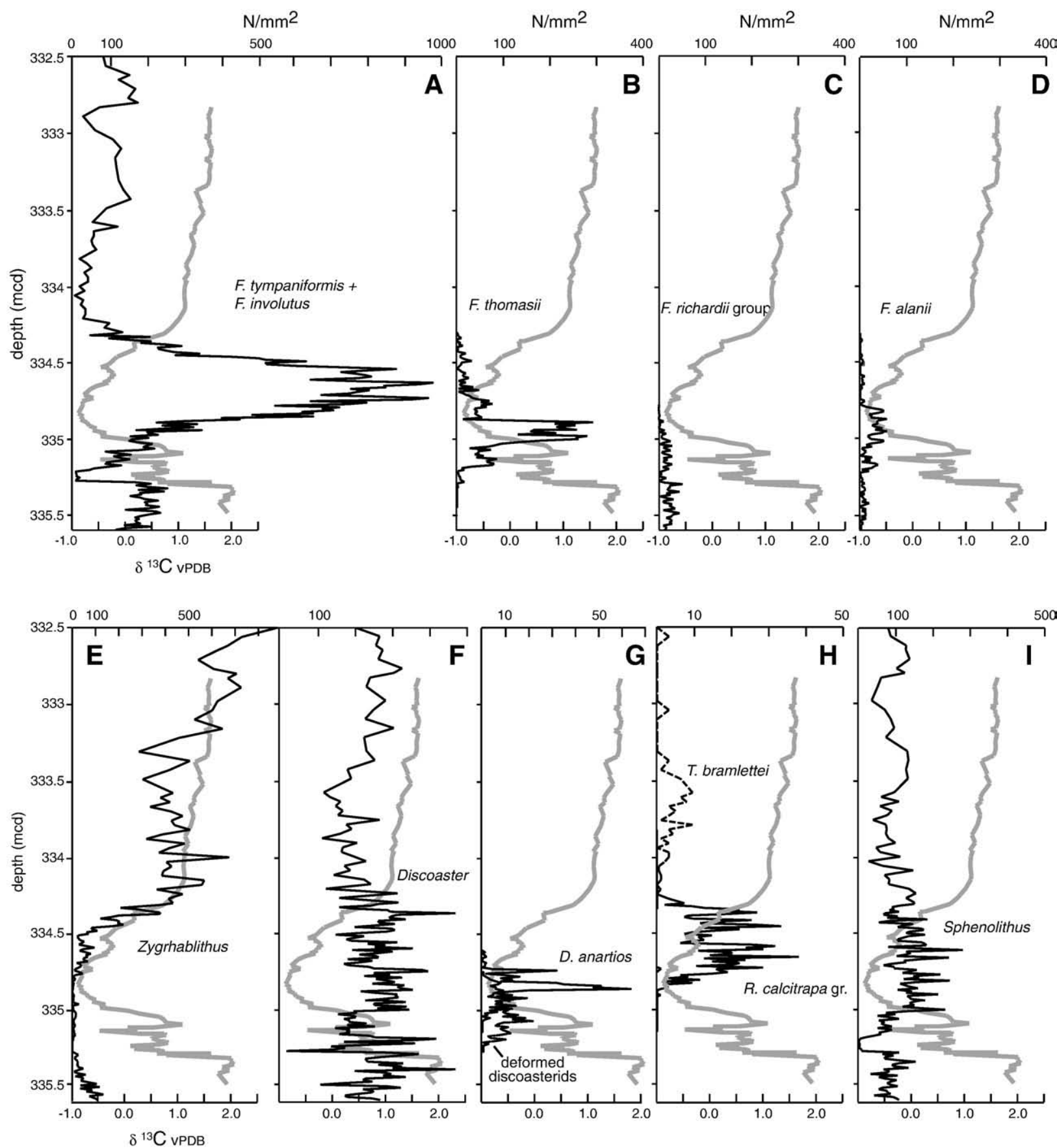

Fig. 2. Abundances of selected nannofossil genera and index taxa at Site1263 plotted together with carbon isotopes (grey line) (Zachos et al., 2005). 
These taxa were excluded from the second series of counts, in which a total of 300 specimens other than Coccolithus and Toweius were counted in all samples, to obtain percentage variations of the so-called non-coccolith fraction.

\section{Results}

\subsection{Site 1263}

The preservation of calcareous nannofossils is moderate to good throughout most of the studied interval at Site 1263 . Only in a $6-\mathrm{cm}$ interval from 335.27 to $335.21 \mathrm{mcd}$, at the base of the CIE, are the effects of dissolution clearly evident. The results of the counts show a stratigraphic succession of changes (Figs. 2-4), which reflect different phases in the evolving photic zone environment together with the changing sea-floor carbonate preservation before, during and after the PETM. The evolutionary changes among the nannofossil assemblages created at least five distinct biostratigraphic marker events over a 74 kyrs time interval, described below as biohorizons N1 to N5 (Fig. 5). With the higher 1-cm sample resolution employed here in the most critical interval, it has been possible to improve the positions of these biohorizons compared to those reported by Zachos et al. (2005, Table S3).

The N1 biohorizon is coincident with the onset of the CIE, and is defined by the prominent decrease in diversity and abundance of Fasciculithus. The characteristic large fasciculith taxa of the uppermost Paleocene such as Fasciculithus richardii, Fasciculithus schaubii, Fasciculithus hayi, Fasciculithus toni and Fasciculithus mitreus, all suddenly disappeared. This event is recorded in Paleocene-Eocene boundary sections globally (Backman, 1986; Monechi et al., 2000; Raffi et al., 2005, Agnini et al., 2006, 2007a). At Site 1263, N1 occurs at $335.28 \mathrm{mcd}$ (Fig. 2C), corresponding to the "0-age" of Röhl et al.
Site 1263
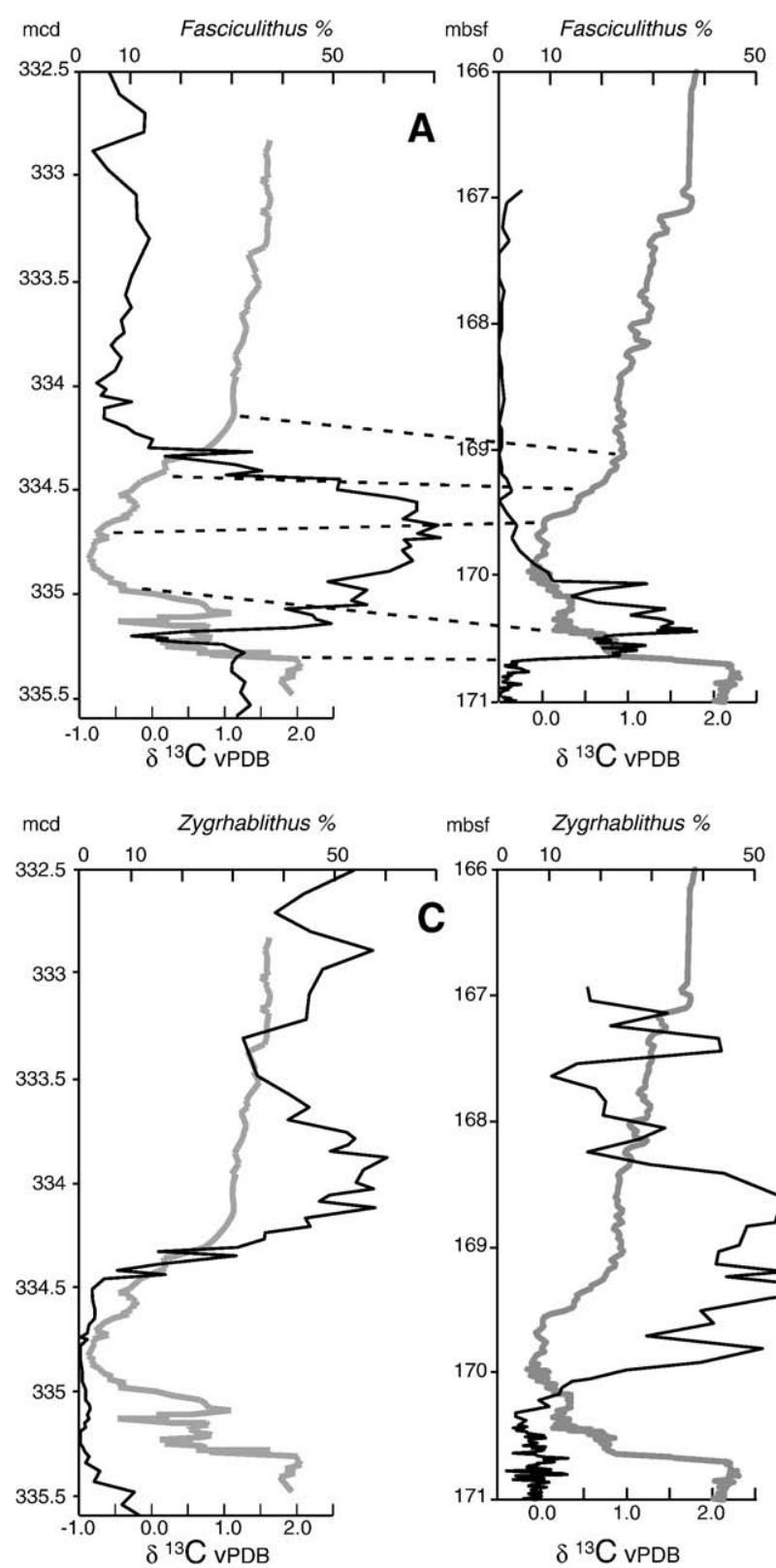

Site 690

mbsf Zygrhablithus \%
Site 1263

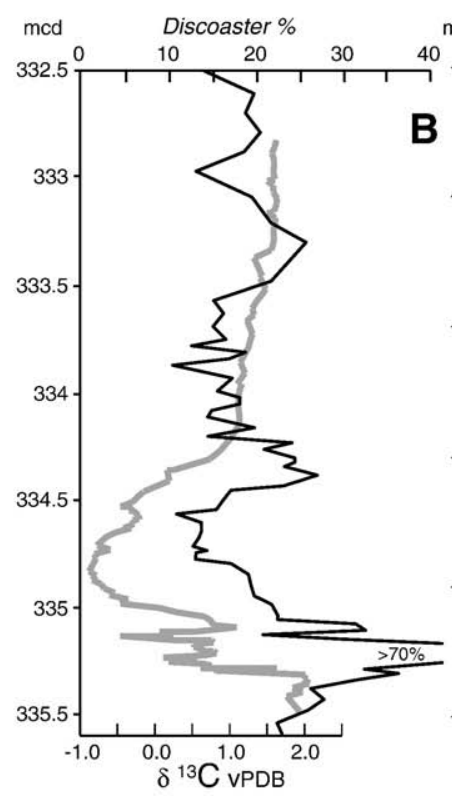

Site 690

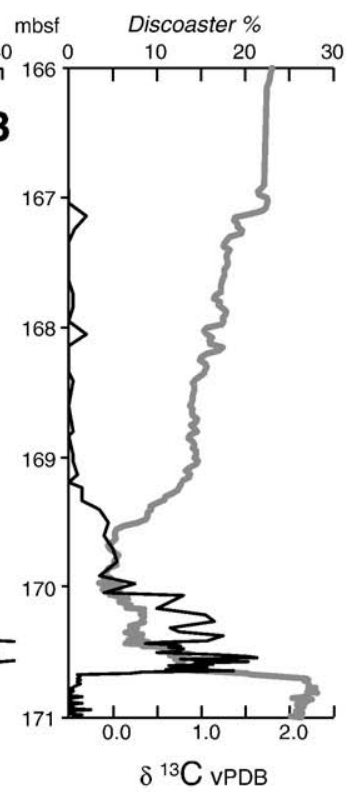

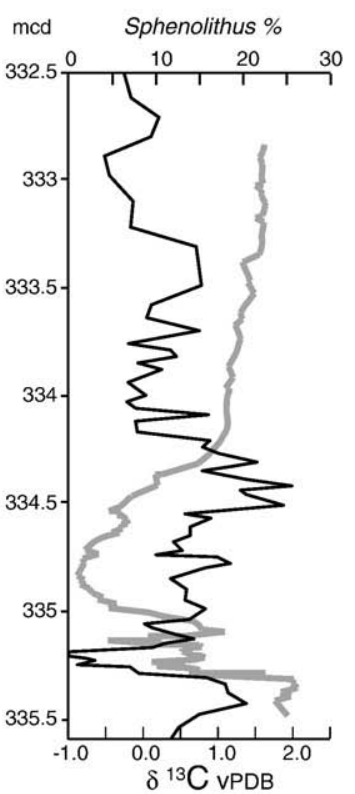

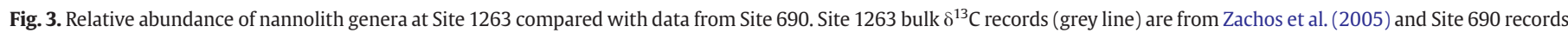
from Bains et al. (1999) and Thomas et al. (2002). Correlation of carbon isotope inflection points is from Zachos et al. (2005). 
Site 1263

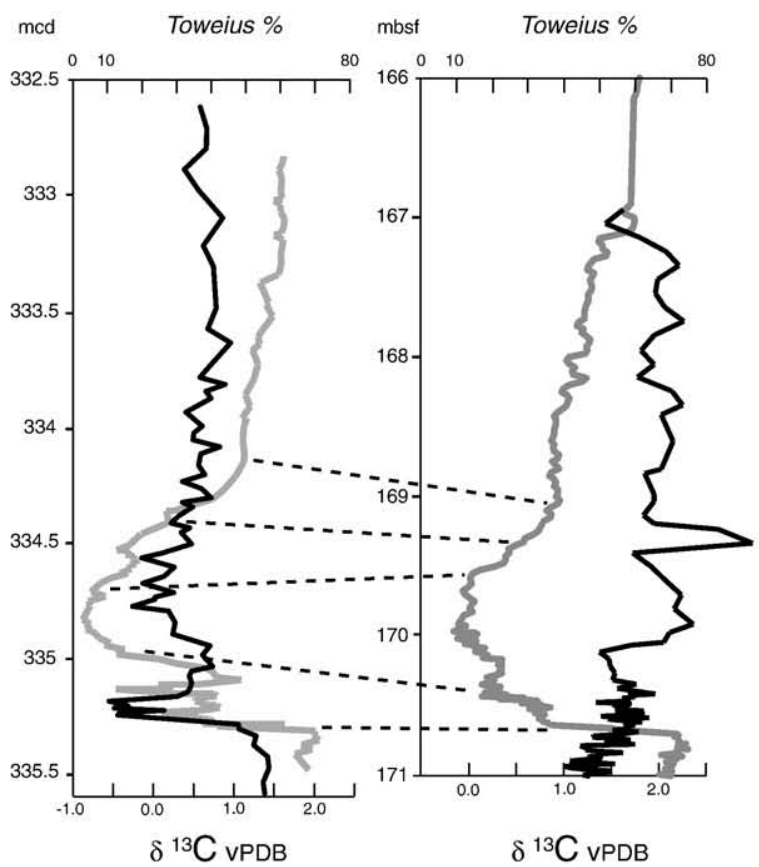

Site 1263

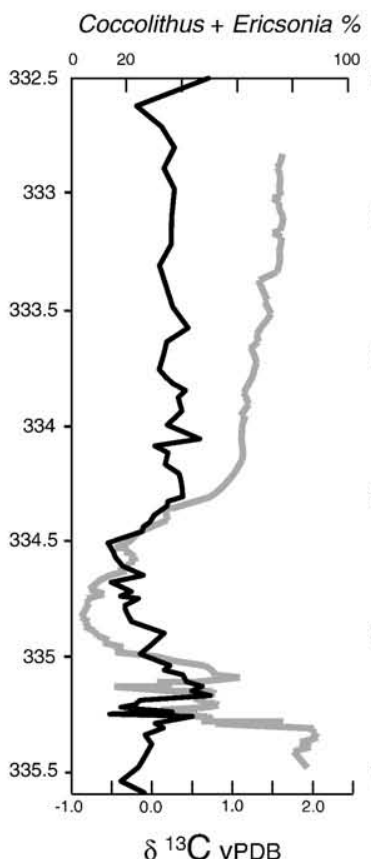

$\delta{ }^{13} C_{\text {VPDB }}$
Site 690

Ericsonia \%

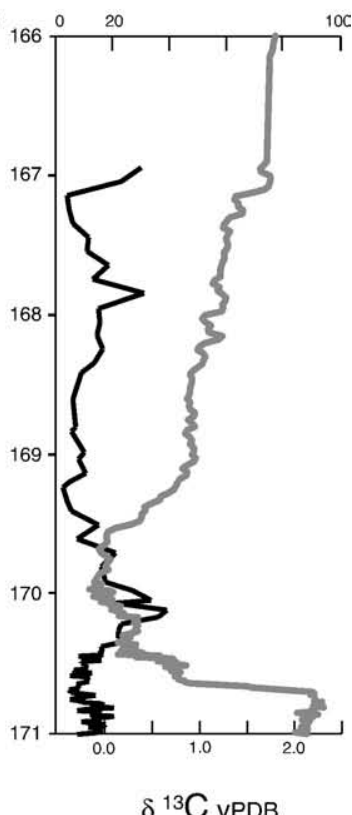

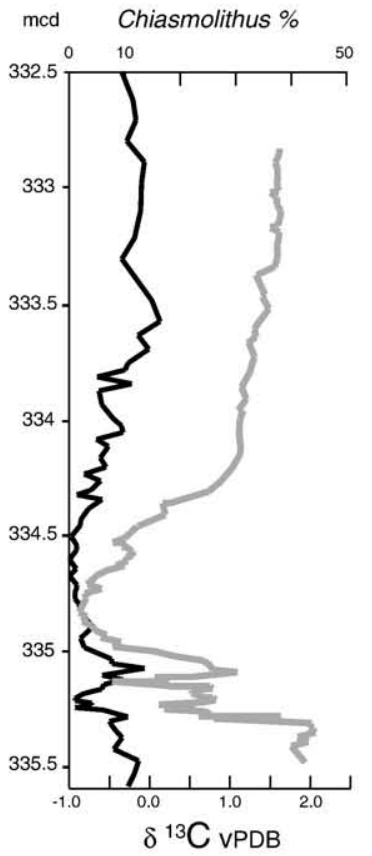

Site 1263

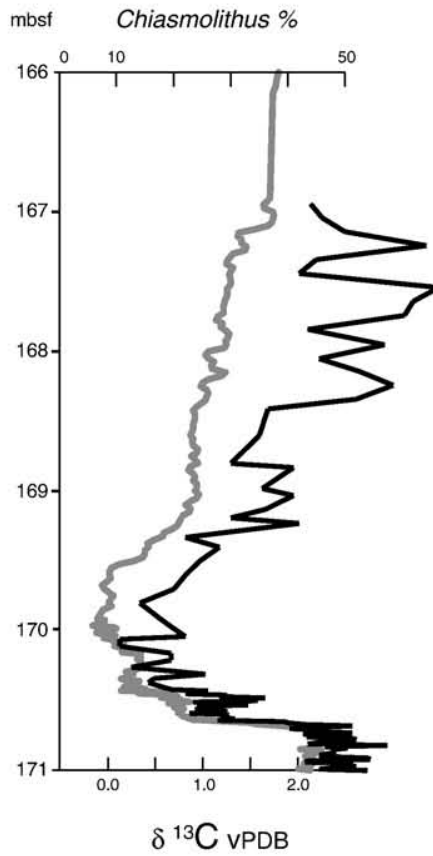

Site 690

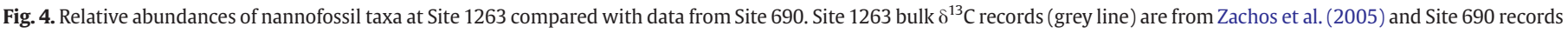
from Bains et al. (1999) and Thomas et al. (2002). Correlation of carbon isotope inflection points is from Zachos et al. (2005).

(2007). In a few samples at the basal part of the PETM, nannofossil assemblages are impoverished and strongly dissolved and show low abundances or absence of Coccolithus, Toweius, Chiasmolithus (Fig. 4). Also Fasciculithus and Sphenolithus show very rare specimens in this interval (Fig. 2A, I), although they are considered relatively dissolution resistant taxa together with the genus Discoaster that, instead, shows a sharp increase in the relative abundance (>70\%) (Fig. 3B). In this interval the Discoaster assemblage is dominated by the robust Discoaster multiradiatus. These data indicate the loss of most other nannofossil taxa in the basalmost interval of the PETM. The genus Zygrhablithus, which is rare in the uppermost Paleocene, temporarily disappears within the PETM (Fig. 2E). Among the surviving fasciculiths, F. tympaniformis and F. involutus are consistently present at fairly high abundances during the PETM (Fig. 2A). Paleocene reworking is extensive in the lower PETM between about 335.07 and $335.02 \mathrm{mcd}$ (Fig. 2C, D). These mixed assemblages of reworked and indigenous taxa must have influenced the isotopic character of the bulk carbonate, which largely is made up of nannofossil carbonate. The intensive reworking of late Paleocene nannofossils may have skewed bulk carbonate $\delta^{13} \mathrm{C}$ values towards higher values in that interval.

The interval between 335.19 and 335.02 mcd contains two biostratigraphic markers, namely the first common occurrence of 
morphotypes that are referable to Fasciculithus thomasii and the evolutionary appearance of peculiar forms of deformed and weakly calcified discoasterids (Fig. 2B, G). These discoasterids have an asymmetrical radial structure with a prominent irregular central knob and most of them can be referred to $D$. anartios. Its first occurrence is used to define the N2 biohorizon at Site 1263 (Fig. 5), which occurred 47 kyrs after the onset of the CIE (Röhl et al., 2007). Malformation is not restricted to $D$. anartios, but appears among specimens of Discoaster mediosus, Discoaster nobilis and Discoaster falcatus. These taxa and $D$. multiradiatus are the major components of discoasterid assemblages within the lower Eocene interval (Ypresian). An abundance peak of the short-lived $F$. thomasii also begins at the N2 level (Fig. 5). The first occurrence of rare, small specimens of Discoaster salisburgensis, and sporadic single specimens of Rhomboaster, further characterizes this interval. The scattered presence of other rare taxa such as Biantholithus, Markalius and Thoracosphaera, which never exceed 2\% of the noncoccolith fraction, is not used in our interpretations of the photic zone environments.

The interval of the $\partial^{13} \mathrm{C}$ minimum between 334.95 and $334.75 \mathrm{mcd}$ is marked by increased abundances of $F$. thomasii and deformed discoasterids, just below the lowermost common and continuous occurrence of the genus Rhomboaster. There is a turnover in abundance between Rhomboaster spp. and F. thomasii, and deformed discoasterids (Fig. 5). The consistent occurrence of the spined $R$. calcitrapa group and R. cuspis is recorded at $334.86 \mathrm{mcd}$, which is used to delineate biohorizon N3 (Fig. 2H). The N3 event occurred 58 kyrs into the PETM according to

Site 1263
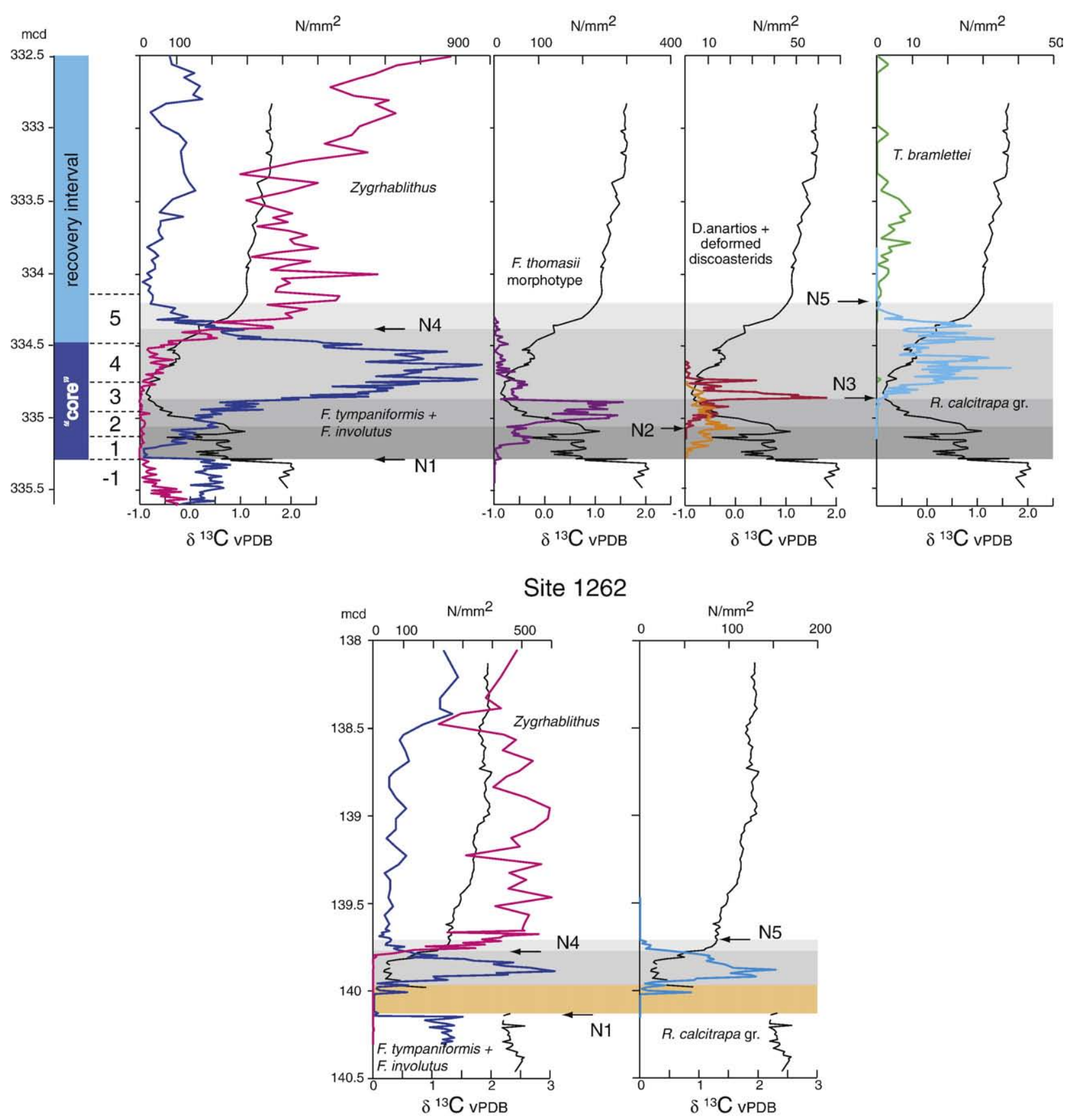

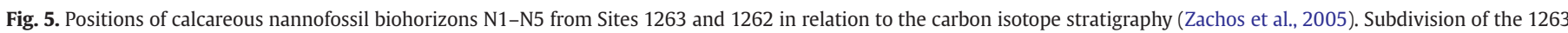
record in core and recovery intervals, and precession cycle numbers which refer to the lithological cycles identified in Fe and Ba RXF data records (after Röhl et al., 2007). 
the cyclostratigraphic model of Röhl et al. (2007). The appearance of Tribrachiatus bramlettei, with rare overgrown specimens, also coincides with biohorizon N3 at Site 1263.

The occurrence of the excursion taxa, $R$. calcitrapa gr., $D$. anartios, and D. araneus (Cramer et al., 2000; Monechi et al., 2000; Aubry, 2001; Bralower, 2002; Kahn and Aubry, 2004), is unique and apparently a global occurrence (Acme) across the PETM interval (Raffi et al., 2005; Agnini et al., 2006, 2007a), although $D$. araneus is missing at Site 1263. The interval between 335.05 and 334.46 mcd has the lightest carbon isotope values. This interval is also characterized, in terms of calcareous nannofossil changes, by $(i)$ high abundances of fasciculiths $\left(\geq 600\right.$ specimens $/ \mathrm{mm}^{2}$ ) (Fig. 2A) comprising $20 \%$ of the total assemblage and $50 \%$ of the non-coccolith assemblage (Fig. $4 \mathrm{~A}$ ), (ii) a persistent absence of Zygrhablithus (Fig. 2E), (iii) a temporary decline in abundance of Discoaster (Fig. 3B), Toweius, Coccolithus and Chiasmolithus (Fig. 4A-C), and (iv) an increase in abundance of Sphenolithus (Figs. 2I, 3D).

A sharp decrease of Fasciculithus (Fig. 2A) occurs in the upper CIE, at the beginning of the recovery interval where bulk $\delta^{13} \mathrm{C}$ values start to recover (increase) and $\mathrm{CaCO}_{3}$ content increases to over $60 \%$. Concomitant with this decline of fasciculiths, Zygrhablithus increases in abundance (Fig. 2E). This cross-over in abundance between Fasciculithus and Zygrhablithus at 334.38 mcd is used to define biohorizon N4. The N4 event occurred 66 kyrs into the PETM according to the cyclostratigraphic model of Röhl et al. (2007). This event is consistently recorded just above the Paleocene/Eocene boundary in different oceanic settings (Bralower, 2002;
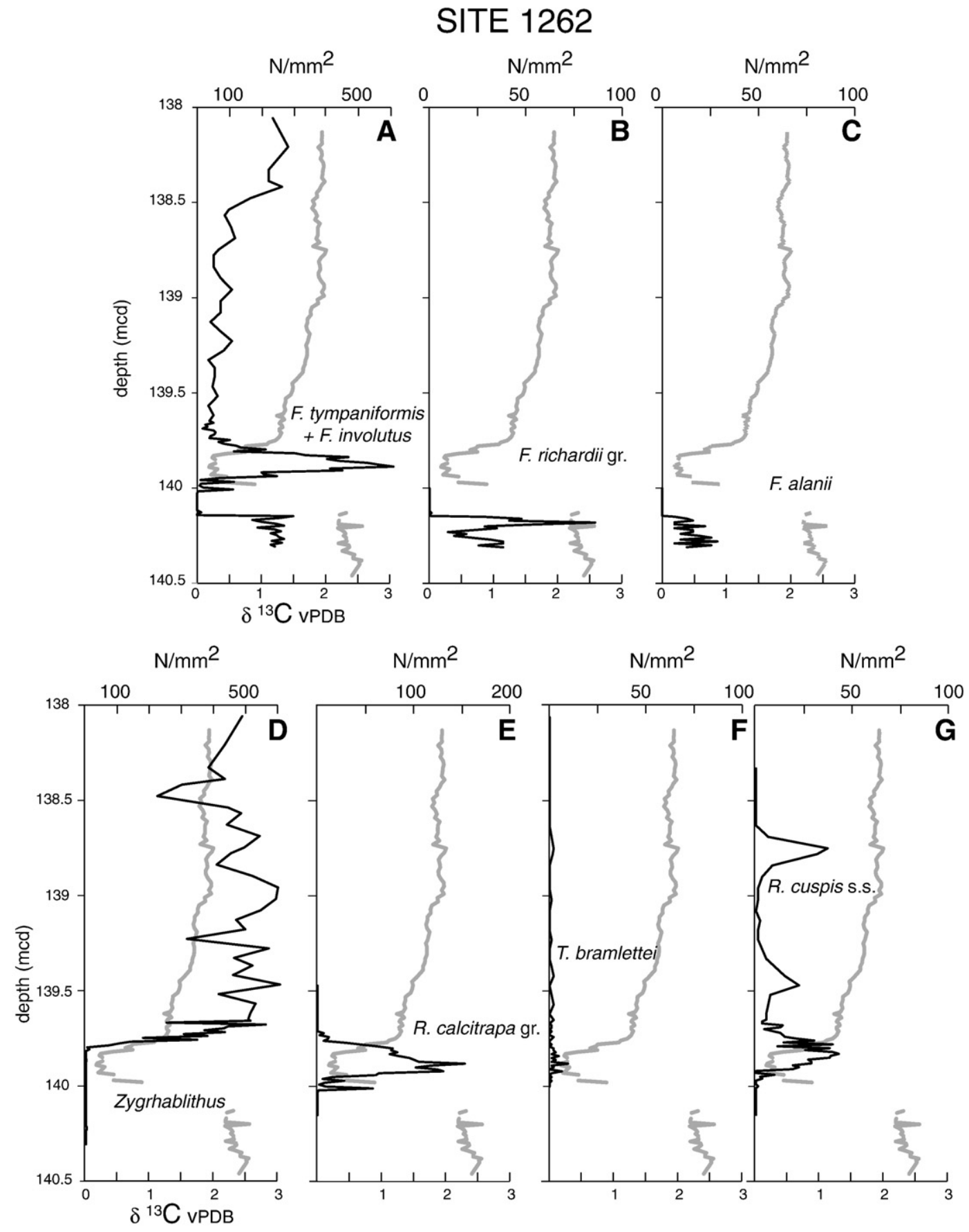

Fig. 6. Abundances of selected index taxa at Site1262 plotted together with carbon isotopes (grey line) (Zachos et al., 2005). 
Tremolada and Bralower, 2004; Gibbs et al., 2006; Tremolada et al., 2007). Bralower (2002) suggested that Zygrhablithus may have simply occupied the ecological niche vacated by Fasciculithus.

The highest occurrence of the spined Rhomboaster spp. was observed at 334.27 mcd (Fig. 5), which is used to define biohorizon N5. The N5 event occurred 74 kyrs into the PETM, where $\mathrm{CaCO}_{3}$ contents stabilized at around $90 \%$ (Zachos et al., 2005). The R. calcitrapa gr. thus has a restricted range in the upper part of the PETM at Site 1263. The N5 event is coeval with an increase in abundance of T. bramlettei (Fig. $2 \mathrm{H}$ ). Rare specimens of Braarudosphaera bigelowi were observed close to the $\mathrm{N} 5$ event. The interval between biohorizons $\mathrm{N} 4$ and N5 is characterized by increasing relative abundance of Discoaster and Sphenolithus (Fig. 3B, D).

Some nannofossil taxa show abundance patterns that are similar to the carbon isotope curve. This is particularly evident for Zygrhablithus in the upper part of the PETM (Figs. 2E, 3C), within the early stages of the ${ }^{13} \mathrm{C}$ recovery interval. Abundances of Coccolithus, Toweius and, to a lesser extent, Chiasmolithus (Fig. 4), are grossly mirrored by the $\delta^{13} \mathrm{C}$ record. In contrast, an inverse relationship is observed between $\delta^{13} \mathrm{C}$ and abundances of Fasciculithus (Fig. 2A).

\subsection{Site 1262}

The interval between 141.14 and 140.02 mcd is largely barren of nannofossils at Site 1262 (Fig. 6) because of intense carbonate dissolution (Zachos et al., 2005). Biohorizon N1 (Fig. 5) coincides with the base, at $140.145 \mathrm{mcd}$, of the 12 -cm barren interval (Fig. 6). $D$. anartios (N2) and the coeval peak abundance $F$. thomasii are not preserved at Site 1262. From the beginning of the PETM recovery interval and upsection, the distribution of key taxa is similar at Sites 1262 and 1263 . This interval is marked by the gradual recovery of carbonate preservation. At the deep Site 1262, however, the nannofossil assemblages are clearly affected by dissolution throughout the recovery interval, as reflected by high abundances of dissolution resistant taxa such as Rhomboaster (Fig. 6E). Biohorizon N4 corresponds to the sharp decrease of fasciculiths at $139.79 \mathrm{mcd}$ (Fig. 6A), where Zygrhablithus spp. re-enters the stratigraphic record (Fig. 6D). Biohorizon N5, the highest occurrence of the spined Rhomboaster spp., is observed at 139.72 mcd (Fig. 5).

\section{Discussion}

Biohorizons N1 to N5 represent five distinct and biostratigraphically useful events among the nannofossil assemblages that occurred over 74 kyrs. This concentration of evolutionary change in a marine phytoplankton group over such a brief geologic time is absolutely unique. No other 74-kyrs interval shows so many distinct biostratigraphic events in any part of the Cenozoic Era. It therefore appears reasonable to conclude that these biostratigraphic events represent biological responses to highly variable and/or extreme conditions in the photic zone environment. Temperature, nutrient cycling, and carbon geochemistry are the most obvious underlying factors that may have influenced the observed compositional and abundance variations among the calcareous nannoplankton assemblages during the PETM.

The nannofossil assemblages at Sites 1263 and 1262 show trends that are both unique and similar to those observed at other localities, providing an opportunity to constrain preservational biases from primary environmental signals. To isolate regional from global signals, we compare the Site 1263 record with data derived from studies of the well-preserved specimens of Site 690 (Bralower, 2002; Figs. 3, 4).

\subsection{Photic zone environments and preservational biases}

Since productivity and calcite export from the photic zone should have been similar at Sites 1263 and 1262, major differences in composition and abundance among the calcareous nannofossil assemblages are interpreted to represent preservational artifacts caused by depth dependent dissolution. For example, the peak abundance of the $R$. calcitrapa gr. between 139.95 and 139.9 mcd (Fig. 6E) at Site 1262 is not present at 1263, and thus likely represents one such artifact.

Other changes, however, presumably reflect variations in the photic zone environments. This interpretation is based on the fact that the evolving calcareous nannofossil assemblages clearly correlate to precession cycles delineated within the PETM using X-Ray Fluorescence (XRF) core scanning records (Röhl et al., 2007). The XRF cycles are partially caused by carbonate dissolution, but in our records each precession cycle has its own characteristic assemblage features (Fig. 5). For example, the peak abundance of $F$. thomasii corresponds to cycle 2 , the peak in abundance of $D$. anartios to cycle 3 , the increase of $R$. calcitrapa gr. to cycle $3 / 4$ transition, the decline in abundance of F. thomasii and deformed discoasterids and 'peak' of Fasciculithus to cycle 4 , and the distinct increase of Zygrhablithus to cycle 4/5 transition. This series of biostratigraphic events and intervening assemblages do not primarily represent carbonate dissolution artifacts, but rather indicate that the observed variability in composition and abundance among the calcareous nannofossil assemblages over the brief PETM interval were induced by orbitally paced changes in the photic zone environment.

Although carbonate dissolution at Site 1263 was less severe than at the deep Site 1262, it was still more severe than at Site 690, implying that dissolution should have affected the 'moderately to well' preserved nannofossil assemblages at Site 1263. Although the composition of the assemblages as well as the export of biogenic calcite was likely different between the sites, comparison with Site 690 allows us to assess some impacts of dissolution at Site 1263. An example of dissolution related bias at Site 1263 is reflected in relative abundances of Discoaster. At the very onset of the PETM, nannofossil abundances are strongly reduced in a few samples, mainly being represented by a few discoasterids (Fig. 2). Three of these samples therefore show relative abundances of Discoaster of $>70 \%$ (Fig. 3B). It appears reasonable to attribute this brief Discoaster abundance increase at Site 1263 to a shallowing lysocline and carbonate dissolution rather than a change in the input signal, because members of this genus are artificially concentrated when the biogenic carbonate at the sediment-water interface is strongly dissolved (Wise, 1977). When the relative abundances of other taxa decrease due to dissolution, abundance of Discoaster increases. These other taxa include Sphenolithus and Fasciculithus at Site 1263 (Fig. 3). The decrease of these genera thus primarily reflect dissolution, suggesting that it is difficult to interpret the abundance variations in the lowermost PETM as observed at Site 1263 in terms of trophic level or temperature because there, the original input signals have been masked and biased by carbonate dissolution. Once carbonate dissolution begins to severely blur the photic zone input signals, it will be difficult to disentangle paleoecologically induced variability from preservational effects at any given time.

\subsection{Discoaster-Fasciculithus-Sphenolithus abundance variations}

At Site 690, Bralower (2002) inferred conditions of increased oligotrophy during the PETM, based on sharp increases in abundance of Discoaster and Fasciculithus at its onset (Fig. 3A, B). Subsequently, Tremolada and Bralower (2004), Gibbs et al. (2006) and Tremolada et al. (2007) suggested that similar oligotrophic conditions were extended to all open ocean photic zone environments. The record at Site 1263 does not support such an interpretation. A dissolution induced Discoaster abundance spike over $3 \mathrm{~cm}$ at the very onset of the PETM at Site 1263 is followed, within the lower PETM, by a return to pre-PETM and postPETM abundance values (Fig. 3B). This stratigraphic development of relative abundances of Discoaster over the PETM at Site 1263 differs from the better-preserved and corresponding interval at Site 690 .

In the middle part of the CIE, Discoaster and Fasciculithus do not covary at Site 1263 (Fig. 2A, F; Fig. 3A, B), which would be expected if both represent warm and oligotrophic conditions (Haq and Lohmann, 
1976; Chepstow-Lusty et al., 1992; Bralower, 2002; Gibbs et al., 2006; Tremolada et al., 2007). Moreover, the neighbouring Site 1262 shows high abundances of Fasciculithus throughout the upper Paleocene, and in the lowermost Eocene just prior to the extinction of this genus (Agnini et al., 2007b, Fig. 3). Except for the brief PETM interval during which the input signal is obscured by carbonate dissolution, the photic zone environment over the Walvis Ridge sites was generally favourable for Fasciculithus production, and the 'peak' abundance shown in Fig. $3 \mathrm{~A}$ appears to represent the very end of a much longer and regionally successful productivity history (Agnini et al., 2007b, Fig. 3), not shown in our data that are restricted to about 170 kyrs at Site 1263.

Abundances of Discoaster during the PETM are, like those of Fasciculithus, fully compatible with the longer-term abundance history before and after the PETM in the Walvis Ridge region (Agnini et al., 2007b, Fig. 3). Thus, discoasterids did not react to increasing PETM temperatures in the sub-tropical Walvis Ridge region, nor do their abundances suggest any exceptional changes in trophic levels across the PETM interval. Agnini et al.'s (2007b) data rather suggest a slight increase in productivity across the PETM interval if assuming that temperatures did not decrease and therefore that decreasing abundances of discoasterids imply increasing photic zone productiv- ity. Assuming that temperature and trophic level shifts did occur in the Walvis Ridge region, these apparently did not result in any clearly discernable changes in Discoaster and Fasciculithus abundances.

In contrast, Discoaster and Fasciculithus seem to co-vary during the PETM at Site 690 (Fig. 3A, B), and the abundance behaviour of these taxa has been interpreted to reflect warmer and oligotrophic conditions that made it possible for these taxa to briefly thrive in southern high latitude waters (Bralower, 2002; Gibbs et al., 2006; Tremolada et al., 2007). The PETM interval is about 30\% thicker at Site 690 compared to Site 1263 (Röhl et al., 2007), which presumably reflects a combination of higher productivity and less carbonate dissolution at Site 690. The differences in abundance behaviour between Sites 690 and 1263 before and during the PETM therefore could be ascribed to a difference in temperature between the subtropical Site 1263 and the sub-polar Site 690. For example, at Site 1263 , fasciculiths and discoasterids are consistently more abundant in comparison to Site 690, reflecting warmer sub-tropical waters. And at Site 1263 the genus Coccolithus, mainly represented by Coccolithus pelagicus, which had a lower latitude preference during the early Paleogene, prevails over the higher latitude thriving genera Toweius and Chiasmolithus (Haq and Lohmann, 1976). However, Sites 1263 and 690 do share similar patterns of compositional and abundance
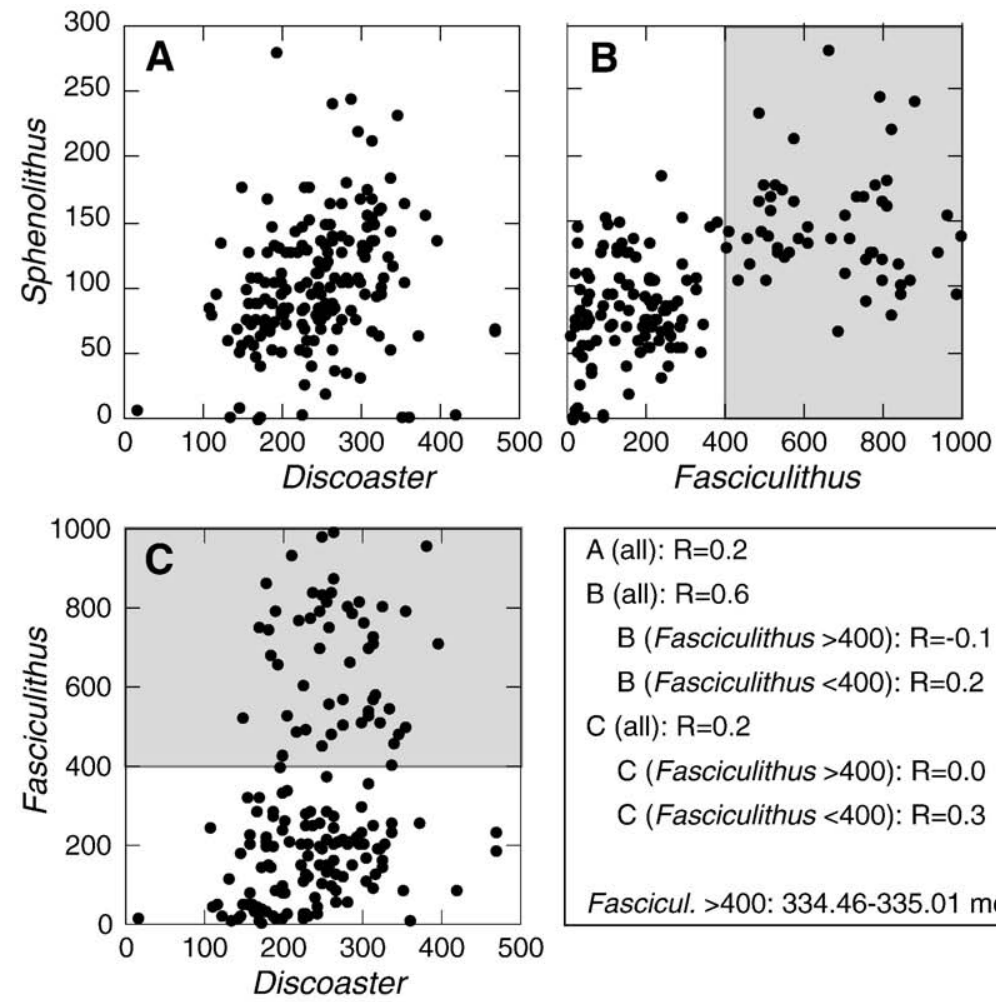
$A$ (all): $R=0.2$
$B$ (all): $R=0.6$
$\mathrm{B}$ (Fasciculithus >400): $\mathrm{R}=-0.1$
$\mathrm{B}$ (Fasciculithus $<400)$ : $\mathrm{R}=0.2$

$C$ (all): $R=0.2$

C (Fasciculithus $>400$ ): $\mathrm{R}=0.0$

C (Fasciculithus <400): $\mathrm{R}=0.3$

Fascicul. >400: 334.46-335.01 mcd

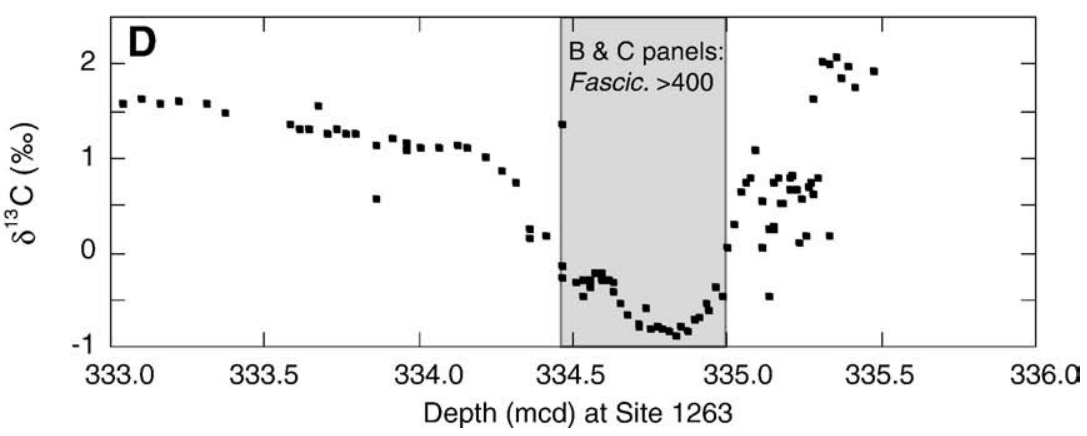

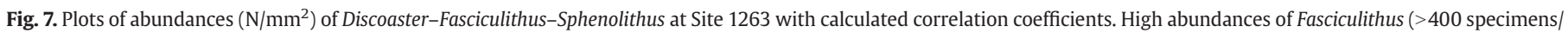
$\mathrm{mm}^{2}$; grey shading) are restricted to the core CIE. 
changes, for example the replacement of Fasciculithus by Zygrhablithus (Fig. 3), even if the Fasciculithus/Zygrhablithus abundance cross-over is time-transgressive, occurring about 30 kyrs later at Site 1263. The abundance increase of Zygrhablithus in the lower part of the PETM recovery interval (Fig. 3C) represents the first common occurrence of this taxon in the Walvis Ridge region because it is rare or absent in upper Paleocene and lower PETM sediments (Agnini et al., 2007b).

Thus, the warming during the PETM was the major factor controlling nannofossil assemblages at the high latitude Site 690, favouring a consistent increase in abundance of Discoaster and Fasciculithus. In the sub-tropical Walvis Ridge region, however, conditions did not become more favourable for these taxa, and the influence of the temperature increase was negligible in controlling assemblage abundances. The strong thermal control on distribution is consistent with observations of modern plankton (Bopp et al., 2001).

Calcareous nannofossil census data in Paleocene/Eocene sections from Site 690, Wilson Lake at the New Jersey margin, and Site 1209 from the Shatsky Rise, have been employed to calculate correlation coefficients between different genera (Bralower, 2002; Gibbs et al., 2006) in order to facilitate reconstructions of photic zone paleoenvironments. These calculations, however, are based on relative abundance (\%) data, and yield a closed sum problem: when one genus increase in abundance some other taxonomic component must decrease by default. We have plotted abundances of Discoaster, Fasciculithus (Fig. 7A) and Sphenolithus (Fig. 7C) against each other and calculated correlation coefficients on the $\mathrm{N} / \mathrm{mm}^{2}$ data (Fig. 7), which are not affected by the closed sum problem. The Discoaster/Sphenolithus and Discoaster/Fasciculithus scatter plots do not show any significant positive or negative correlations for the Site 1263 data, contrary to the expected result, because nannoplankton having similar ecological preferences (warm and oligotrophic) ought to produce more coherent responses to changes of temperature and nutrient availability in the photic zone environment. A weak positive correlation may be deduced from the Sphenolithus/Fasciculithus relationship (Fig. 7B) at Site 1263. However, high abundances (>400 specimens $/ \mathrm{mm}^{2}$ ) of Fasciculithus are entirely confined to the peak phase of the PETM. And despite the large variation of Fasciculithus abundances in that interval (Fig. 7), there is no significant correlation among the Sphenolithus/Fasciculithus ( $R=-0.1$; Fig. 7B) or Discoaster/ Fasciculithus $(R=0.0$; Fig. $7 \mathrm{C})$ relationships. It's clear that we still have an incomplete understanding of the significance of abundance variations among different calcareous nannofossil genera in terms of photic zone paleoecology, especially give the limited datasets that are available.

\subsection{Calcareous nannofossil malformation and increased $\mathrm{CO}_{2}$ concentrations in the water column}

Deformed and weakly calcified Discoaster specimens (D. anartios, and deformed $D$. nobilis, $D$. falcatus and $D$. mediosus) are common during the PETM interval. Similar deformation effects of other Discoaster taxa have been observed in a subsequent early Eocene hyperthermal (ETM2; also referred to as $\mathrm{H} 1$ or Elmo) (Raffi and De Bernardi, 2008). We interpret the unusual and weakly calcified $F$. thomasii morphotype, which occur together with the deformed discoasterids during the PETM, to represent a stressed response to unusual photic zone conditions during the early Eocene hyperthermals. Scanning electron micrograph analyses of these peculiar nannoliths in the PETM interval provide further details with respect to their preservation and calcification (Raffi and De Bernardi, 2008). The taxonomic status of discoasterids is unclear visavi coccolitophorids. Yet, it appears reasonable to assume that these nannoliths, that show anomalous morphologies in terms of malformation and calcification during the early Eocene hyperthermals, may represent the fossil documentation of a process observed in modern calcifying phytoplankton species. Several experiments in which nanno- plankton are exposed to elevated $\mathrm{CO}_{2}$ concentrations have resulted in reduced calcite production and malformation (Riebesell et al., 2000; Zondervan et al., 2001; Rost and Riebesell, 2004; Langer et al., 2006). Consequently, the distinct occurrences of malformed nannofossils during two brief early Eocene hyperthermals which are characterized by massive inputs of $\mathrm{CO}_{2}$ into the oceans, and hence lower $\mathrm{pH}$, imply a possible cause and effect relationship.

\subsection{Influence of nannofossil assemblage compositions on bulk sediment carbon isotopes}

Nannofossils are the dominant component of biogenic carbonate sediments at Walvis Ridge, and therefore dictate the bulk sediment stable isotopic composition. At Site 1263, major changes in assemblages correspond to more-or-less pronounced inflection points in bulk $\delta^{13} \mathrm{C}$. Both at Site 1263 and Site 690, some of the abundance shifts in the nannofossil records occur in correspondence with inflections in the two bulk $\delta^{13} \mathrm{C}$ records (Figs. 2, 3, 5). However, for inflection points correlated between the two sites (Zachos et al., 2005) (Figs. 3, 4), the composition and abundances of the nannofossil assemblages differ between Sites 1263 and 690. At first glance, this may suggest that the inflection points in the two carbon isotope records are not caused by assemblage changes because they are replicated in two geographically separated sedimentary records, having different nannofossil characteristics which reflect differences in paleoenvironments. This is consistent with findings of an investigation of calcareous nannofossil isotopic distribution across the Paleocene/Eocene boundary which demonstrated that the carbon isotopic composition of individual Paleocene genera such as Toweius, Chiasmolithus, Discoaster and Fasciculithus are consistently offset through the PETM (Stoll, 2005). In essence, the trends in bulk nannofossil carbonate, made up of different taxa, as well as for the "near-monogeneric" taxa, did not change as a function of abundances.

\section{Conclusions}

Our investigation of compositional and abundance variations among calcareous nannofossil assemblages at two Walvis Ridge sites in the South Atlantic across the earliest Eocene PETM interval yielded the following findings:

- Five biostratigraphically useful and distinct calcareous nannofossil events (N1 through N5) occur over a 74 kyrs period in the early part of the PETM, using the floating timescale of Röhl et al. (2007);

- this rapid evolution, partly characterized by the emergence of malformed and/or weakly calcified morphotypes, among the calcareous nannoplankton over such a brief geologic time is unique in a Cenozoic perspective, and is taken to indicate stressed, unstable and/or extreme photic zone environments;

- the two sites investigated for this study are located less than $50 \mathrm{~km}$ apart in distance, but $2 \mathrm{~km}$ apart in terms of water depth, which means any abundance differences are purely preservational in origin;

- nannofossil assemblage at Site 1263 is strongly biased by dissolution in a 6-cm interval of the basal portions of the PETM. The series of biostratigraphic events and assemblage turnovers represent, however, orbitally paced changes in the photic zone environments and hence paleoecological variability;

- increased abundances of the genera Discoaster-FasciculithusSphenolithus during the PETM have been interpreted to represent warm and oligotrophic photic zone environments in open ocean sites. At Site1263, however, these genera do not show any marked, paleoecologically induced, abundance variability if compared to background abundances before and after the PETM. If anything, Discoaster abundances can be interpreted to represent increased PETM productivity at the Walvis Ridge sites; 
- the Discoaster/Fasciculithus, Discoaster/Sphenolithus and Fasciculithus/Sphenolithus relationships show no significant correlation, which is unexpected because these taxa are considered to represent warm and oligotrophic photic zone environments and should therefore show relatively coherent abundance responses to changes in temperature and productivity. This indicates that multiple factors may have contributed to the assemblage changes and that further research is required to improve our understanding of the factors that control calcareous nannofossil abundance;

- presence of malformed and/or weakly calcified taxa during two of the early Eocene hyperthermals implies a similar cause and effect relationship. A reasonable explanation may be the hugely increased carbon dioxide concentrations in all parts of the water column, including the photic zone, during these hyperthermals;

- comparisons between Sites 1263 and 690 reveal, on one hand, similar shapes and amplitudes of bulk $\delta^{13} \mathrm{C}$ isotopic records and, on the other, relevant differences in relative nannofossil assemblage compositions. This implies that assemblage changes had little effect on the inflection points in the nannofossil $\delta^{13} \mathrm{C}$ records, which is consistent with Stoll's (2005) results that different Paleocene nannofossil taxa are characterized by virtually uniform carbon isotope values.

\section{Acknowledgements}

Claudia Agnini and Bianca De Bernardi are thanked for support, stimulating discussions and exchange of ideas on nannofossils. This research used samples provided by the Ocean Drilling Program (ODP) sponsored by the U.S. National Science Foundation and participating countries under management of Joint Oceanographic Institutions. Comments by Tim Bralower and Elisabetta Erba on an earlier version of the manuscript are appreciated. Funding for this research was provided from the Italian Murst-PRIN 2006-2007 to IR (national coordinator I. Premoli Silva). JB was supported by the Swedish Research Council, JCZ by NSF Grant EAR-0628719 and AS by the Netherlands Organisation for Scientific Research (NWO) VENI grant 863.07.001.

\section{Appendix A. Taxonomic list of calcareous nannofossils}

The list includes all the taxa cited in the paper. The taxonomy and bibliographical references follow Perch-Nielsen (1985) and Aubry $(1984,1988,1989,1990)$.

\section{Biantholithus Bramlette \& Martini, 1964}

B. bigelowi Gran \& Braarud, 1935) Deflandre, 1947

Chiasmolithus Hay, Mohler \& Wade, 1966

Coccolithus Schwarz, 1894

C. pelagicus Schiller, 1930

Discoaster Tan Sin Hok, 1927

D. anartios Bybell \& Self-Trail, 1995

D. araneus Bukry, 1971

D. falcatus Bramlette \& Sullivan, 1961

D. mediosus Bramlette \& Sullivan, 1961

D. multiradiatus Bramlette \& Riedel, 1954

D. nobilis Martini, 1961

D. salisburgensis Stradner, 1961

Ericsonia robusta Perch Nielsen, 1977

Fasciculithus Bramlette \& Sullivan, 1961

Fasciculithus alanii Perch-Nielsen, 1971

F. hayi Haq, 1971

F. involutus Bramlette \& Sullivan, 1961

F. mitreus Gartner, 1971

F. richardii Perch-Nielsen, 1971

F. schaubii Hay \& Mohler, 1967

F. thomasii Perch-Nielsen, 1971

F. toni Perch-Nielsen, 1971
F. tympaniformis Hay \& Mohler, 1967

Markalius Bramlette \& Martini, 1964

Octolithus Perch-Nielsen, 1973

Rhomboaster Bramlette \& Sullivan, 1961

R. cuspis Bramlette \& Sullivan, 1961

R. calcitrapa Gartner, 1971

R. spineus (Romein, 1979) Perch-Nielsen, 1984

Sphenolithus Deflandre in Grasse, 1952

Thoracosphaera Kamptner, 1927

Toweius Hay \& Mohler, 1967

Toweius tovae Perch-Nielsen, 1971

T. bramlettei Proto Decima et al., 1975

Zygrhablithus Deflandre, 1959

Z. bijugatus Deflandre, 1959

\section{Appendix B. Supplementary data}

Supplementary data associated with this article can be found, in the online version, at doi:10.1016/j.marmicro.2008.12.005.

\section{References}

Abdul Aziz, H., Hilgen, F.., van Luijk, G.M., Sluijs, A., Kraus, M.J., Pares, J.M., Gingerich, P.D. 2008. Astronomical climate control on paleosol stacking patterns in the upper Paleocene-lower Eocene Willwood Formation, Bighorn Basin, Wyoming. Geology 36, 531-534. doi:510.1130/G24734A.

Agnini, C., Muttoni, G., Kent, D.V., Rio, D., 2006. Eocene biostratigraphy and magnetic stratigraphy from Possagno, Italy: the calcareous nannofossil response to climate variability. Earth Planet. Sci. Lett. 241, 815-830. doi:10.1016/j.epsl.2005.11.005.

Agnini, C., Fornaciari, E., Rio, D., Tateo, F., Backman, J., Giusberti, L., 2007a. Responses of calcareous nannofossil assemblages, mineralogy and geochemistry to the environmental perturbations across the Paleocene/Eocene boundary in the Venetian PreAlps. Mar. Micropaleontol. 63, 19-38. doi:10.1016/j.marmicro.2006.10.002.

Agnini, C., Fornaciari, E., Raffi, I., Rio, D., Röhl, U., Westerhold, T., 2007b. High-resolution nannofossil biochronology of middle Paleocene to early Eocene at ODP Site 1262: implications for calcareous nannoplankton evolution. Mar. Micropaleontol. 64, 215-248. doi:10.1019/j.marmicro.2007.05.003.

Aubry, M.-P., 1984. Handbook of Cenozoic calcareous nannoplankton, book 1, Ortholithae (Discoaster). Micropaleontol. Press, Am. Mus. of Nat. Hist., New York. 263 pp.

Aubry, M.-P., 1988. Handbook of Cenozoic calcareous nannoplankton, book 2, Ortholithae (Holococcoliths, Ceratoliths, Ortholiths and other). Micropaleontol. Press, Am. Mus. of Nat. Hist., New York. 279 pp.

Aubry, M.-P., 1989. Handbook of Cenozoic calcareous nannoplankton, book 3, Ortholithae (Pentaliths and other), Heliolithae (Fasciculiths, Sphenoliths and others). Micropaleontol. Press, Am. Mus. of Nat. Hist., New York. 279 pp.

Aubry, M.-P., 1990. Handbook of Cenozoic calcareous nannoplankton, book 4, Heliolithae (Helicoliths, Cribriliths, Lopadoliths and other). Micropaleontol. Press, Am. Mus. of Nat. Hist., New York. 381 pp.

Aubry, M.-P., 2001. Provincialism in the photic zone during the LPTM. In: Ash, A., Wing, S. (Eds.), Climate and Biota of the Early Paleogene. International Meeting, Powell, Abstract Volume, Powell, p. 6.

Aubry, M.-P., Requirand, C., Cook, J., 2000. The Rhomboaster-Tribrachiatus lineage: a remarkable succession of events from 55.5 to 53.2 Ma. GFF 122, 15-18.

Aubry, M.-P., Ouda, K., Dupuis, C., Berggren, W.A., Van Couvering, J.A., Members of the Working Group on the Paleocene/Eocene Boundary, 2007. The Global Standard Stratotype-section and Point (GSSP) for the base of the Eocene Series in the Dababiya section (Egypt). Episodes 30 (4), 271-286.

Backman, J., 1986. Late Paleocene to middle Eocene calcareous nannofossil biochronology from the Shatsky Rise, Walvis Ridge and Italy. Palaeogeogr. Palaeoclimatol. Palaeoecol. 57, 43-59.

Backman, J., Shackleton, N.J., 1983. Quantitative biochronology of Pliocene and early Pleistocene calcareous nannoplankton from the Atlantic, Indian and Pacific Oceans. Mar. Micropaleontol. 8, 141-170.

Backman, J., Raffi, I., 1997. In: Curry, W.B., Shackleton, N.J., Richter, C., Bralower, T.J. (Eds.), Calibration of Miocene Nannofossil Events to Orbitally Tuned Cyclostratigraphies from Ceara Rise. Proc. ODP, Sci. Results, vol. 154. Ocean Drilling Program, College Station, TX, pp. 83-99.

Bains, S., Corfield, R.M., Norris, R.D., 1999. Mechanisms of climate warming at the end of the Paleocene. Science 285, 724-727.

Bralower, T.J., 2002. Evidence of surface water oligotrophy during the Paleocene-Eocene thermal maximum: nannofossil assemblage data from Ocean Drilling Program Site 690, Maud Rise, Weddel Sea. Paleoceanography 17 (2), 1029-1042. doi:10.1029/ 2001PA000662.

Bopp, L., Monfray, P., Aumont, O., Dufresne, J.-L., Le Treut, H., Madec, G., Terray, L., Orr, J.C., 2001. Potential impact of climate change on marine export production. Glob. Biogeochem. Cycles 15, 81-99.

Bybell, L.M., Self-Trail, J.M., 1995. Evolutionary, biostratigraphic and taxonomic study of calcareous nannofossils from a continuous Paleocene-Eocene boundary section in New Jersey. U.S. Geol. Survey Prof. Pap. 155436 pp. 
Bybell, L.M., Self-Trail, J.M., 1997. Late Paleocene and early Eocene calcareous nannofossils from three boreholes in an onshore-offshore transect from New Jersey to the Atlantic continental rise. Proc. Ocean Drill. Prog. Sci. Results 150X, 91-110.

Chepstow-Lusty, A., Shackleton, N.J., Backman, J., 1992. Upper Pliocene Discoaster abundance variations from the Atlantic, Pacific and Indian oceans: the significance of productivity pressure at low latitudes. Mem. Sci. Geol. 43, 357-373.

Cramer, B.S., Miller, K.G., Aubry, M.-P., Olsson, R.K., Wright, J.D., Kent, D.V., Browning, J.V., 2000. The Bass River Section: an exceptional record of the LPTM event in a neritic setting. Bull. Geol. Soc. Fr. 170, 883-897.

Dickens, G.R., O'Neil, J.R., Rea, D.K., Owen, R.M., 1995. Dissociation of oceanic methane hydrate as a cause of the carbon isotope excursion at the end of the Paleocene. Paleoceanography 10, 965-971.

Gibbs, S.J., Bralower, T.J., Bown, P.R., Zachos, J.C., Bybell, L.M., 2006. Shelf and open-ocean calcareous phytoplankton assemblages across the Paleocene-Eocene thermal maximum: implication for global productivity gradients. Geology 34 (4), 233-236.

Giusberti, L., Rio, D., Agnini, C., Backman, J., Fornaciari, E., Tateo, F., Oddone, M., 2007. Mode and tempo of the Paleocene-Eocene thermal maximum in an expanded section from the Venetian pre-Alps. Geol. Soc. Am. Bull. 119, 391-412. doi:10.1130/ B25994.1.

Haq, B.U., Lohmann, G.P., 1976. Early Cenozoic calcareous nannoplankton biogeography of the Atlantic Ocean. Mar. Micropaleontol. 1, 119-194.

Iglesias-Rodriguez, M.D., Halloran, P.R., Rickaby, R.E.M., Hall, I.R., Colmenero-Hildago, E., Gittins, J.R., Green, D.R.H., Tyrrel, T., Gibbs, S.J., von Dassow, P., Rehm, E., Armburst, E.V., Boessenkool, K.P., 2008. Phytoplankton calcification in a high- $\mathrm{CO}_{2}$ world. Science 320, 336-340. doi:10.1126/science.1154122.

Kahn, A., Aubry, M.-P., 2004. Provincialism associated with the Paleocene/Eocene thermal maximum: temporal constraint. Mar. Micropaleontol. 52, 117-131.

Kennett, J.P., Stott, L.D., 1991. Abrupt deep-sea warming, palaeoceanographic changes and benthic extinctions at the end of the Palaeocene. Nature 353, 225-229.

Langer, G., Geisen, M., Baumann, K.-H., Kläs, J., Riebesell, U., Thoms, S., Young, J.R., 2006. Species-specific response of calcifying algae to changing seawater carbonate chemistry. Geochem. Geophys.Geosyst. 7. doi:10.1029/2005GC001227.

Monechi, S., Angori, E., von Salis, K., 2000. Calcareous nannofossil turnover around the Paleocene/Eocene transition at Alamedilla (southern Spain). Bull. Soc. Géol. France 171 (4), 477-489.

Mutterlose, J., Linnert, C., Norris, R., 2007. Calcareous nannofossils from the PaleoceneEocene Thermal maximum of the equatorial Atlantic (ODP Site 1260B): evidence for tropical warming. Mar. Micropaleontol. 65, 13-31.

Perch-Nielsen, K., 1985. Cenozoic calcareous nannofossils. In: Bolli, H.M., et al. (Ed.), Plankton Stratigraphy. Cambridge University Press, New York, pp. 427-554.

Raffi, I., De Bernardi, B., 2008. Response of calcareous nannofossils to the PaleoceneEocene thermal maximum: observations on composition, preservation and calcification in sediments from ODP Site 1263 (Walvis Ridge -SW Atlantic). Mar. Micropaleontol. 69, 119-138.

Raffi, I., Backman, J., Pälike, H., 2005. Changes in calcareous nannofossil assemblage across the Paleocene/Eocene transition from the paleo-equatorial Pacific Ocean. Palaeogeogr. Palaeoclimat. Palaeoc. 226, 93-126.

Riebesell, U., Zondervan, I., Rost, B., Tortell, P.D., Zeebe, R.E., Morel, F.M.M., 2000. Reduced calcification of marine plankton in response to increased atmospheric $\mathrm{CO}_{2}$. Nature 407, 364-367.

Röhl, U., Westerhold, T., Bralower, T.J., Zachos, J.C., 2007. On the duration of the Paleocene-Eocene thermal maximum (PETM). Geochem. Geophys. Geosyst. 8, Q12002. doi:10.1029/2007GC001784.

Romein, A.J.T., 1979. Lineages in early Paleogene calcareous nannoplankton. Utrecht Micropaleont. Bull. 22231 pp.

Rost, B., Riebesell, U., 2004. Coccolithophores and the biological pump: responses to environmental changes. In: Thierstein, H.R., Young, J.R. (Eds.), Coccolithophores,
From Molecular Processes to Global Impact. Springer Verlag, Berlin, Germany, pp. 99-125.

Sluijs, A., Schouten, S., Pagani, M., Woltering, M., Brinkhuis, H., Sinninghe Damsté, J.S., Dickens, G.R., Huber, M., Reichart, G.-J., Stein, R., Matthiessen, J., Lourens, L.J., Pedentchouk, N., Backman, J., Moran, K., Expedition 302 Scientists, 2006. Subtropical Arctic Ocean temperatures during the Palaeocene/Eocene thermal maximum. Nature 441, 610-613.

Sluijs, A., Bowen, G.J., Brinkhuis, H., Lourens, L.J., Thomas, E., 2007. The PalaeoceneEocene thermal maximum super greenhouse: biotic and geochemical signatures, age models and mechanisms of global change. In: Williams, M., et al. (Ed.), Deep Time Perspectives on Climate Change: Marrying the Signal from Computer Models and Biological Proxies. The Micropalaeontological Soc., Special Publ. The Geological Society, London, pp. 323-347.

Stoll, H.M., 2005. Limited range of interspecific vital effects in coccolith stable isotopic records during the Paleocene-Eocene thermal maximum. Paleoceanography 20, PA1007. doi:10.1029/2004PA001046.

Thomas, D.J., Zachos, J.C., Bralower, T.J., Thomas, E., Bohaty, S., 2002. Warming the fuel for the fire: evidence for the thermal dissociation of methane hydrate during the Paleocene-Eocene thermal maximum. Geology 30, 1067-1070.

Tremolada, F., Bralower, T.J., 2004. Nannofossil assemblage fluctuations during the Paleocene-Eocene thermal maximum at Sites 213 (Indian Ocean) and 401 (North Atlantic Ocean): palaeoceanographic implications. Mar. Micropaleontol. 52, 107-116.

Tremolada, F., Erba, E., Bralower, T.J., 2007. A review of calcareous nannofossil changes during the early Aptian oceanic anoxic event $1 \mathrm{a}$ and the Paleocene-Eocene thermal maximum: the influence of fertility, temperature, and $\mathrm{pCO}_{2}$. In: Monechi, S., Coccioni, R., Rampino, M.R. (Eds.), Large Ecosystem Perturbations: Causes and Consequences. Geol. Soc. Am. Special Paper, 424, pp. 87-96. doi:10.1130/2007.2424(05).

von Salis, K., Monechi, S., Bybell, L.M. Self-Trail, J., Young, J.R., 2000. Remarks on the calcareous nannofossil genera Rhomboaster and Tribrachiatus around the Paleocene/Eocene boundary. GFF 122, 138-140.

Wei, W., Zhong, S., 1996. Taxonomy and magnetobiochronology of Tribrachiatus bramlettei and Rhomboaster, two genera of calcareous nannofossils. J. Paleontol. 70 (1), 7-22.

Westerhold, T., Röhl, U., Laskar, J., Raffi, I., Bowles, J., Lourens, L.J., Zachos, J.C., 2007 On the duration of magnetochrons $\mathrm{C} 24 \mathrm{r}$ and $\mathrm{C} 25 \mathrm{n}$ and the timing of early Eocene global warming events: implications from the Ocean Drilling Program Leg 208 Walvis Ridge depth transect. Paleoceanography 22 PA2201. doi:10.1029/ 2006PA001322.

Wise, S.W., 1977. Chalk formation: early diagenesis. In: Anderson, N.R., Malahoff A. (Eds.), The Fate of Fossil Fuel $\mathrm{CO}_{2}$ in the Oceans. Plenum Press, New York, pp. 717-739.

Zachos, J.C., Pagani, M., Sloan, L.C., Billups, K., Thomas, E., 2001. Trends, rhythms, and aberrations in global climate 65 Ma to present. Science 292, 686-693. doi:10.1126/ science.1059412.

Zachos, J.C., Kroon, D., Blum, P., et al., 2004. Early Cenozoic extreme climates: the Walvis Ridge transect. Proc. Ocean Drill. Program, Initial Rep 208 http://www odp.tamu. edu/publications/208_IR/208ir.htm.

Zachos, J.C., Röhl, U., Schellenberg, S.A., Sluijs, A., Hodell, D.A., Kelly, D.C., Thomas, E., Nicolo, M., Raffi, I., Lourens, L.J., McCarren, H., Kroon, D., 2005. Rapid acidification of the ocean during the Paleocene-Eocene thermal maximum. Science 308, 1611-1615.

Zondervan, I., Zeebe, R.E., Rost, B., Riebesell, U., 2001. Decreasing marine biogenic calcification: a negative feedback on rising atmispheric $p \mathrm{CO}_{2}$. Global Biogeochem. Cycles 15 (2), 507-516. 